\title{
FORMAS DE PROSAIISMO LÍRICO: BENEDETTI, EL COLOQUIALISMO \\ Y LA MÉTRICA CAMUFLADA
}

\section{VARIATIONS OF PROSAISM AS LYRIC CODE: BENEDETTI, THE COLLOQUIAL LANGUAGE AND THE METRIC IN DISGUISE}

\author{
CARLOS Mármol \\ Universidad de Sevilla
}

\begin{abstract}
Resumen: El objeto de este ensayo es estudiar la relación entre la retórica del prosaísmo presente en la poesía del escritor Mario Benedetti y la métrica. El análisis de ambos elementos en una selección de poemas demuestra que la supuesta libertad con la que el poeta construye el verso no es, en determinadas ocasiones, completa, sino que, en mayor o menor medida, está planteada inevitablemente sobre una pauta métrica ortodoxa, aunque con significativas variaciones que responden al deseo de Benedetti de acercar su obra al lector cotidiano.
\end{abstract}

Palabras clave: Mario Benedetti, poesía, tradición, prosaísmo, lírica.

Abstract: The purpose of this essay is to study the relationship between de rhetoric of prosaism as lyric code in Mario Benedetti's poetry in relation with the metrics rules. 
Both elements appears in a sort of poems which shows that the alleged full freedom in the verse is not complete in many occasions. The relaxed metric pattern, although with several variations, appears in Benedetti's poems as a fruit of his desire to get close his work to the reader.

Keywords: Mario Benedetti, poetry, tradition, prosaism, lyric. 
Siempre me instaron a que fuera otro pero mi terquedad es infinita ${ }^{1}$ MARIO BENEDETTI

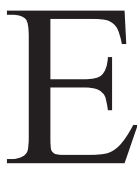

1 poeta uruguayo Mario Benedetti entiende la lírica como un canto a la libertad personal. En una entrevista publicada en noviembre de 1986 declara: «La poesía es el más libre y flexible de los géneros: no tiene una estricta dimensión normativa (aunque haya formas poéticas como un soneto o una décima, que sí la tienen), ni un rutina temática (aunque a veces el amor o la política pueden volverse temas rutinarios), ni límites a la experimentación, ni extensiones fijas. Un poema puede abarcar cientos de páginas o apenas tres versos $\rangle^{2}$. A tenor de estas palabras, pudiera pensarse que la opción lírica de Benedetti es insumisa a los cánones métricos. Nada más opuesto a la realidad. Según Mónica Mansour ${ }^{3}$, la lírica del autor uruguayo se caracteriza por una tensión entre la tradición y la innovación. En esta misma idea incide Carmen Alemany, que cree que la irrupción de los poetas conversacionales, entre los que se encuentra Benedetti, «no significó una ruptura respecto a la poética anterior, simplemente se trata de una continuidad que viene desde aquella poesía modernista que a finales de siglo luchó por la renovación del lenguaje poético afincándose en lo postparnasiano y lo postsimbolista» ${ }^{4}$. La idea de renovación poética de

${ }^{1}$ Benedetti, M.: «Otherness», en Las soledades de Babel. Madrid: Visor, 1991, p. 20.

2 Costa, Marithelma, López, Adelaida: Las dos caras de la escritura. Puerto Rico: Universidad de Puerto Rico, 1988, p. 27.

3 Mansour, Mónica: Tuya, mía, de otros: la poesía coloquial de Mario Benedetti. México DF: UNAM, 1979.

${ }^{4}$ Alemany, Carmen: Poética Coloquial Hispanoamericana. Alicante: Universidad de Alicante, 1997, p. 15. 
Benedetti parte de la voluntad de conseguir una claridad poética que, en Hispanoamérica y otras partes del mundo, consiste en el uso del verso libre, en prescindir -en apariencia- de ciertas convenciones poéticas y en una lírica más accesible, sin perder por eso su condición artística.

Las líneas maestras de esta opción lírica están explicadas por el mismo Benedetti en un libro $^{5}$ en el que el propio poeta entrevista a varios autores de su generación. Aboga en él por establecer un diálogo con el lector para «aludirlo, no eludirlo» y defiende una lírica accesible, diáfana. «Poetas comunicantes significa la preocupación de la actual poesía latinoamericana en comunicar, en llegar a su lector, en incluirlo también a él en su buceo, en su osadía, y a la vez en su austeridad $»^{6}$. A lo largo de la extensa obra del autor uruguayo se suceden distintas etapas ${ }^{7}$ en las que su poesía adoptará tonos dispares, aunque la nota común de todas ellas es su apuesta por la claridad. Benedetti no escribe ningún tratado sobre su idea de la poesía, sino que la define en cuatro poemas -incluidos en distintos libros-donde expresa el lugar exacto desde donde le interesa hablar. A modo de ejemplo véase el poema «Arte Poética», incluido en Contra los puentes levadizos:

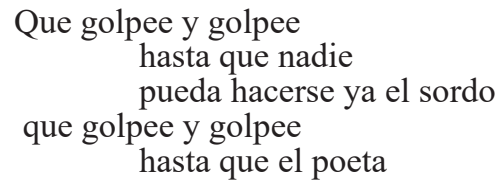

Que golpee y golpee hasta que nadie pueda hacerse ya el sordo que golpee y golpee hasta que el poeta

sepa

o por lo menos crea que es a él a quien llaman ${ }^{8}$

${ }_{5}^{5}$ Benedetti, Mario: Los poetas comunicantes. México DF: Marcha Editores, 1972.

${ }^{6}$ Ibid., p. 16.

7 Francisca Noguerol, en su estudio sobre la antología poética Los espejos las sombras (Salamanca: Universidad de Salamanca, 1999, p. 28), distingue cuatro grandes periodos en la producción literaria de Benedetti: la etapa inicial (1948-1960), marcada por poemas sobre la alienación del individuo en un escenario urbano, que en este caso es Montevideo; una segunda, centrada en el compromiso político (1961-1973) y dos posteriores momentos vinculados al exilio (1973-1985) y al regreso al Uruguay, un desexilio que duraría hasta 1999.

8 Benedetti, Mario: «Arte Poética», en Contra los puentes levadizos. Madrid: Visor, 1966, p. 457. 
Benedetti usa la poesía como una herramienta para despertar al lector (y al propio poeta) de sus ensoñaciones, instándole (aunque de forma no directa) a que asuma un cierto compromiso. $\mathrm{Su}$ interés es la poesía que conecta con el lector, al que se trata como un prójimo y a quien no se le habla desde ningún atrio. El poeta se dirige a un igual, obviando las barreras retóricas impuestas por la tradición poética, pero sin renunciar a los instrumentos métricos. Benedetti tiene poemas escritos en verso libre, sin puntuación, escalonando o rompiendo los versos, pero en el ritmo que late en su interior se vislumbra el metro tradicional, que en ocasiones se disimula con una distribución versal concebida paradójicamente para ocultar esta naturaleza. La ruptura con la tradición que persigue no es violenta, sino natural y relativa. Es un camino que se entiende mejor si tenemos en cuenta cuál fue la evolución general del versolibrismo hispanoamericano?

La poesía coloquial que se cultiva a partir de los años sesenta forma parte de una corriente secundaria del canon hispánico. Nace como un fruto tardío del modernismo - la gran revolución poética en español-y de su autor emblemático, Rubén Darío. $\mathrm{Su}$ génesis está en las postrimerías de este movimiento, en esa voz tardía de Darío y de otros poetas que, de cierta manera, terminan cuestionando el modernismo de primera hora. Darío recurrió al prosaísmo en algunos poemas. Ya no es el Darío de la pomposidad, sino un Darío en fuga, el poeta de la Epístola a la señora Lugones, un texto alejado de los decorados fabulosos de los orígenes y donde parece decidido a hacer emerger su voz más auténtica. En esta poesía ya están presentes elementos de la poesía coloquial. Fernández Retamar precisa: «en la poesía de Darío ya están el ilogicismo, el desmantelamiento de la cohesión, lo inconsciente y lo anormal, la tensión propia de la poesía moderna; la ampliación de lo decible, una abolición de las censuras morales que prepara el terreno a la desenvoltura expresiva de Vallejo y Neruda. Hay en su poesía humor, prosaísmo y esa marca inconfundible de la poesía moderna, la voluntad de reflexión teórica sobre la práctica poética incluso en el seno mismo del poema». ${ }^{10}$

\footnotetext{
${ }^{9}$ Alemany, Carmen: Poética Coloquial..., cit., p. 41.

10 Fernández Retamar, Roberto: «Rubén Darío en las modernidades de nuestra
} 
Vallejo, Borges y Neruda transitan por esta misma vía apoyados en los recursos de las vanguardias: el abandono de la puntuación (Apollinaire), la rima, la disposición tipográfica o la predilección por un lenguaje cotidiano sustentado en la imagen y la intertextualidad. En el caso de Benedett ${ }^{11}$, fue la lectura inicial de un poeta menor argentino -Baldomero Fernández Moreno, representante de la corriente del sencillismo- la que le descubrió que el camino de la poesía contemporánea pasaba por la claridad. La poesía coloquial termina así acrisolando una fórmula lírica propia -dicho sea con las salvedades necesarias- cuya caracterización toma recursos, instrumentos y variantes poéticas del postmodernismo y las vanguardias. Su principal innovación consiste en la ruptura del «hermetismo» poético, presente todavía en los antecedentes citados, para establecer un vínculo directo, sin intermediarios, con el lector. Este acercamiento implica desmitificar la vieja figura del poeta predestinado, el vate elegido por los dioses de los románticos. La herramienta usada para esta inversión jerárquica del sujeto poético será la ironía, que en realidad se aplica con más intensidad sobre la figura del poeta que sobre la poesía. El distanciamiento lírico de los poetas coloquiales nunca llega a minar por completo las bases naturales de lo poético. Su intención es convertir el yo lírico en un nosotros. Con este fin eligen la narratividad, el léxico común, la evocación y la mezcla de géneros. La métrica se relaja sin dramas. La puntuación se disuelve. Queda el ritmo, sostenido por un caudal de recursos de dicción.

\begin{abstract}
II
La música de la poesía, entonces, debe ser una música latente en el habla común de su época ${ }^{12}$

T. S. Eliot
\end{abstract}

El prosaísmo es una suma de distintos elementos retóricos y temáticos que configuran una determinada forma de expresión

América». Ponencia pronunciada en el Congreso Rubén Dario: La tradición y el proceso de modernización. Universidad de Illinois, Mayo, 1988.

11 Costa, Marithelma, López, Adelaida: Las dos caras de la escritura, cit., p. 23.

12 Eliot, T. S: Sobre poesía y poetas. Buenos Aires: Sur, 1959, p. 25. 
lírica. Entre ellos, el más notable es el verso libre, cuestión estudiada de forma fragmentaria debido a su naturaleza «fugitiva $\rangle^{13}$. El concepto de verso libre (o versolibrismo) plantea una contradicción en sus términos iniciales: si entendemos por verso aquel que obedece al patrón métrico vigente en cada lengua en un determinado periodo histórico, su ausencia vendría a negar su existencia y el objeto mismo de estudio. No es el caso. El verso libre es una realidad literaria asumida. Según Rafael Lapesa ${ }^{14}$, «con su asentimiento culmina la busca de ritmos menos sujetos a los patrones métricos heredados, y más obedientes al íntimo decurso del pensamiento poético individual».

Sobre esta cuestión trata una extensa monografía firmada por Isabel Paraíso ${ }^{15}$, que demuestra que en el ámbito hispánico existen antecedentes de la versificación irregular, germen del versolibrismo moderno, cuyo nacimiento se podría situar entre 1885 y 1887, cuando Laforgue y Kahn hacen una defensa expresa de «un verso con libertad absoluta, sin encabalgamiento, concebido como una unidad de sentido, y donde la rima, como auxiliar secundario, puede ser reforzada o atenuada o sustituida por la aliteración, donde los metros tienen un número no fijo de sílabas y el ritmo del periodo poético, más bien que en el número de sílabas, resulta de la cantidad flotante, de la amplia regularidad de los acentos» ${ }^{16}$. Otra parte de la crítica sitúa el antecedente trascendental del verso amétrico en la publicación de Leaves of Grass, la obra que Walt Whitman dio a imprenta en 1855, unos años antes de la citada formulación teórica de los poetas franceses.

Conviene diferenciar el prosaísmo del versolibrismo. Aunque ambos términos estén íntimamente relacionados, no podemos hablar de una identidad completa: el uso de un estilo poético narrativo o prosaico no implica necesariamente una ruptura métrica, igual que no toda la literatura lírica responde a un mismo patrón de verso. Según Esteban Torre, «las formas

\footnotetext{
${ }^{13}$ Utrera Torremocha, M. ${ }^{\text {a }}$ Victoria: Historia y teoría del verso libre. Sevilla: Padi1la, 2001, p. 25.

14 LAPESA, Rafael: «Prólogo» a PARAíso, Isabel: El verso libre hispánico. Madrid: Gredos, 1985, p. 9.

15 PARaíso, Isabel: El verso libre hispánico, cit.

${ }^{16}$ Ibid., p. 20.
} 
(poéticas) consideradas amétricas, encuentran su razón de ser en los esquemas métricos, de los que representan, según los casos, una confirmación, un desvío o una expectativa frustrada» ${ }^{17}$. Siendo esto así, lo que también resulta nítido es que la versificación irregular está, como apunta María Victoria Utrera Torremocha, «más cerca de las inquietudes de la poesía moderna, un arte caracterizado por la ruptura con la tradición anterior y con las que se sentían entonces como rígidas normas de la versificación $)^{18}$.

El verso libre mantiene la noción de unidad rítmica. A este respecto, conviene insistir, siguiendo a Amado Alonso, en las diferencias existentes entre el ritmo del verso y el de la prosa. Éste último está condicionado por la sintaxis, mientras que el primero es «una figura móvil constituida por los elementos acústicos del lenguaje» ${ }^{19}$. Uno es mecánico, autónomo; el otro brota de «la intuición del poeta $»^{20}$. Según Gili Gaya ${ }^{21}$, el patrón de la unidad rítmica en el verso libre es la frase. La ordenación del tiempo en el verso libre sería más dilatada que en la poesía tradicional, donde los ritmos tenían una recurrencia más alta. Dicho de otra forma: cuanto mayor es la frase, más amplio será el intervalo de tiempo del poema. Incluso puede llegar a volverse casi imperceptible, sobre todo para un oído acostumbrado a las formas métricas tradicionales. Esto explicaría, según Gili Gaya, que «cada versículo sea una unidad melódica, expresiva, voluntaria, deliberada. Hasta tal punto el verso libre desborda la sintaxis que los autores prescinden de la puntuación ortográfica».

En consecuencia, podemos convenir que el prosaísmo lírico concentra su poeticidad sobre un ritmo subjetivo (o interior), sin que esta circunstancia implique un cuestionamiento del ritmo métrico y acentual que, según los casos, puede mantenerse, diluirse o sencillamente ignorarse. Utrera Torremocha habla de la existencia de un «ritmo en cadena $»^{22}$ que iría de un verso a otro,

17 Torre, E.: El ritmo del verso. Murcia: Universidad de Murcia, 1999, pp. 12-13.

18 Utrera TorRemocha: Historia y teoría del verso libre, cit., p. 11.

19 Alonso, Amado: Poesía y estilo de Pablo Neruda. Madrid: Gredos, 1997.

${ }^{20}$ Ibid., p. 122.

${ }^{21}$ Gili Gaya, Samuel: El ritmo de la poesía contemporánea. Barcelona: Universidad de Barcelona, 1956.

${ }^{22}$ Utrera Torremocha, Historia y teoría del verso libre, cit., pp. 181-221. 
perceptible en la sintaxis. «El verso libre sería amétrico, pero no arrítmico. Su ritmo se explicaría por la repetición de representaciones, imágenes o estados afectivos a lo largo del poema ${ }^{23}$. La diferencia con la prosa ordinaria consistiría en el enfoque que adopta el poeta: en la prosa predomina el sentido lógico del discurso; en la poesía prosaica en verso libre la guía serían las intuiciones irracionales. Ya no estamos ante un ritmo silábico, sino conducido por la frase. Incluso para Navarro Tomás, el verso libre es entendido como una atenuación del ritmo respecto al verso regular, no como una ruptura. «El verso libre aparece con ritmo propio, adecuado y espontáneo, sin preocupación métrica ni amétrica y sin la afectación de un hermetismo limitado estrictamente a la intimidad del poeta ${ }^{24}$.

Otra opinión sobre la práctica del verso libre es la de Martin J. Duffell, que se inclina por la tesis de que el prosaísmo poético vinculado al versolibrismo más que a subvertir la tradición viene a ampliar la perspectiva de la poesía como lenguaje lírico ${ }^{25}$. En su opinión, los versolibristas no escriben en prosa con forma de verso, sino que versifican a partir de estructuras menos previsibles que las convencionales, pero que no se identifican exactamente con la prosa ${ }^{26}$. Entiende Duffell los experimentos versolibristas como una forma de buscar un efecto estético imposible de apreciar y comprender en toda su importancia si no lo relacionamos con la poesía tradicional, basada en pautas métricas. Para Duffell, la poesía contemporánea se caracteriza por un equilibrio entre la seguridad -el metro-y la sorpresa -el verso libre-, donde este segundo concepto adquiere presencia sin borrar del mapa al primero. El verso libre tiene su ritmo ${ }^{27}$, sólo que éste ya no está condicionado por el modelo que predominó durante siglos. Los poetas del prosaísmo lírico trabajan el ritmo subjetivo a partir de fórmulas como el encabalgamiento (que no es sino una alteración artificial de la cadencia), la repetición fonética o los versos de dimensión dispar. En el fondo,

$\overline{23}$ Ibid., p. 185.

24 Navarro Tomás, Tomás: Métrica española. Barcelona: Labor, 1991, p. 455.

25 Duffell, Martin J: A New History of English Metre. Londres: Legenda. Modern Humanities Research Association and Maney Publishing, 2008.

26 Ibid., p. 187.

27 Ibid., p. 195. 
se trata de una cuestión de percepción. Cuando la regularidad métrica queda en suspenso, opina Reuven Tsur ${ }^{28}$, el lector suple su ausencia sustituyendo el ritmo acústico:

Whenever metric regularity is suspended, the reader may echo, so to speak, in his short-term memory, the regularity alternating underlying beats, even though they may have no trance in the acostic signal. The reader may compensate, to some extent, for the abscence of the metrical signal, by anticipating the return of regular beats. The poetic rhythm is, essentially, an auditory phenomenon, though also affected by syntax and semantics ${ }^{29}$.

Un poema de Benedetti donde se aprecia esta utilización del versolibrismo es «Dactilógrafo»" ${ }^{30}$. Se trata de un texto de largo aliento que, a la manera de Walt Whitman, ordena sus ritmos con paralelismos y figuras de pensamiento, emulando la tradición bíblica de los sermones. En este caso, es una oración sobre el hastío cotidiano:

$\begin{array}{ll}\text { Montevideo quince de noviembre } & 11 \\ \text { de mil novecientos cincuenta y cinco } & 11 \\ \text { Montevideo era verde en mi infancia } & 11 \\ \text { absolutamente verde y con tranvías } & 12 \\ \text { muy señor nuestro por la presente } & 10 \\ \text { yo tuve un libro del que podía leer } & 12 \\ \text { veinticinco centímetros por noche } & 11 \\ \text { y después del libro del que podía leer } & 14 \\ \text { y yo quería pensar en cómo sería eso } & 14 \\ \text { de no ser de caer como piedra en un pozo } & 14 \\ \text { comunicamos a usted que en esta fecha } & 12 \\ \text { hemos efectuado por su cuenta } & 11 \\ \text { quién era ah sí mi madre se acercaba } & 11 \\ \text { y prendía la luz y no te asustes } & 11 \\ \text { y después la apagaba antes que me durmiera } & 14 \\ \text { el pago de trescientos doce pesos } & 11 \\ \text { a la firma Menéndez \& Solari } & 11 \\ \text { y sólo veía sombras como caballos } & 12 \\ \text { y elefantes y monstruos casi hombres } & 11\end{array}$

$\overline{28}$ Tsur, Reuven: Poetic Rhythm. Structure and Perfomance. Toronto: Sussex Academic Press, 2012, p. 9.

${ }^{29}$ Ibid., p. 9.

30 Benedetti, Mario: Poemas de la oficina (Montevideo: Número, 1956). Madrid: Visor, 1984, p. 21. 


$\begin{array}{lr}\text { y sin embargo aquello era mejor } & 11 \\ \text { que pensarme sin la savia del miedo } & 11 \\ \text { desaparecido como se acostumbra } & 12 \\ \text { en un todo de acuerdo con sus órdenes } & 11 \\ \text { de fecha siete del corriente } & 9 \\ \text { era tan diferente era verde } & 11 \\ \text { absolutamente verde y con tranvías } & 12 \\ \text { y qué optimismo tener la ventanilla } & 12 \\ \text { sentirse dueño de la calle que baja } & 12 \\ \text { jugar con los números de las puertas cerradas } & 13 \\ \text { y apostar consigo mismo en términos severo } & 15 \\ \text { rogámosle acusar recibo lo antes posible } & 14 \\ \text { si terminaba en cuatro o trece o diecisiete } & 14 \\ \text { era que me iba a reír o a perder o a morirme } & 14 \\ \text { de esta comunicación a fin que podamos } & 14 \\ \text { y hacerme tan sólo una trampa por cuadra } & 12 \\ \text { registrarlo en su cuenta corriente } & 10 \\ \text { absolutamente verde y con tranvías } & 12 \\ \text { y el Prado con caminos de hojas secas } & 11 \\ \text { y el olor a eucaliptus y a temprano } & 11 \\ \text { saludamos a usted atentamente } & 11 \\ \text { y desde allí los años y quién sabe. } & 11\end{array}$

El poema tiene 41 versos de pauta irregular, combinándose indistintamente entre ellos versos de diez, once, doce, trece, catorce y quince sílabas. El ritmo predominante es impar. Estamos pues ante un caso de versolibrismo. La mayoría están construidos mediante pausas internas. El poema no está dividido en partes. Es una salmodia en la que se describen vivencias íntimas del sujeto poético, mezcladas con versos que reproducen el lenguaje burocrático de las oficinas. El contraste es total: por un lado hay versos de un evidente afán evocativo; por otro, expresiones de índole administrativa que salpican el texto, y repeticiones, casi oníricas, que buscan expresar el paralelismo entre los dos mundos que conviven dentro del poema.

La principal innovación es de índole estructural: el discurso interior del sujeto lírico, que rememora el Montevideo de su infancia, se altera con la realidad pedestre de la oficina, que sería el espacio del mundo exterior. Desde el punto de vista de la dicción, Benedetti mezcla con pautas de ritmo irregular - primero, cada dos versos, después de forma más amplia o más 
breve, dependiendo del clímax poético- enunciados pertenecientes a estos dos citados universos. El arranque del poema empieza manteniendo un cierto equilibrio entre estos dos ámbitos, pero a partir de aquí se va dando más protagonismo al mundo interior para volver, al final, a restablecer el equilibrio inicial. El patrón rítmico se sostiene en las imágenes y temática de los versos, no tanto en el número de sílabas o en la sucesión acentual. Las figuras retóricas enriquecen el poema: anáforas («verde y con tranvías»), repeticiones, enumeraciones y expresiones coloquiales («no te asustes»). En la aparente sencillez de los versos emerge un prosaísmo que se separa de las técnicas métricas, pero no llega a anularlas por completo.

El versolibrismo, siendo uno de los elementos de la poesía prosaica, no es el único rasgo que la define. Junto a él coexisten otros procedimientos retóricos que contribuyen a forjar la poesía de la trivialidad. El puertorriqueño Daniel Torres, profesor de la Universidad de Ohio, en un estudio dedicado a la poesía del mexicano José Emilio Pacheco ${ }^{31}$, esboza una definición general del prosaísmo lírico a partir de seis puntos. En su opinión, el poema rítmico en prosa se libera del «ritmo y el metro tradicional», abre «semánticamente el poema a significantes no poéticos» (desde una perspectiva tradicional) y acerca el verso a la prosa en búsqueda de un lenguaje real que dote de capacidad poética a los elementos de la realidad inmediata. La prosa se convierte así en el vehículo poético del verso, aunque con el coloquialismo, la conversación en definitiva, como tonalidad principal. El poema abandona cualquier pretensión hermética y aspira a funcionar como un «texto claro que trasunta la irrealidad poética de las palabras al presentar con un lenguaje directo la realidad circundante». Estamos ante la misma palabra ya usada por Benedetti: claridad.

El planteamiento de Torres es un buen punto de partida si se tiene en cuenta que en cada poeta existen variantes personales que impiden la tentación de establecer una regla fija. El punto de coincidencia entre las variantes de poesía coloquial es que los poetas empiezan a reflexionar sobre sus propios límites

31 Torres, Daniel: José Emilio Pacheco. Poesía y poética del prosaísmo. Madrid: Pliegos, 1990. 
y trabajan a partir de cosas reales, terrestres. En el aspecto retórico, Torres cita la utilización de la prosa como nuevo lenguaje poético cuyo único límite es el ritmo, aunque, como ya hemos explicado, bajo una perspectiva distinta a la que existe en los sistemas silábico-métricos y acentuales. El ritmo permanece «liberado de la estructura del metro tradicional». Los poetas sustituyen las herramientas métricas por tácticas retóricas cuya función es suplirlas o complementarlas. Son recursos para lograr efectos poéticos. Entre ellos, Torres cita las estructuras líricas construidas sobre «una enumeración o listado», el «tono coloquial», «la insistencia y reiteración» sobre símbolos y conceptos, «la recontextualización del cliché poético» y el abandono de los signos de puntuación, como si el poema no quisiera llamar la atención sobre sí mismo, sino sobre lo que expresa ${ }^{32}$. En realidad, la ausencia de puntuación no es una novedad: ya lo hicieron las vanguardias. Más exacta nos parece la aportación de Torres al explicar el enfoque del prosaísmo lírico. «Siendo el lenguaje poético insólito, el prosaísmo habla de lo insólito pero desde un origen conocido: la realidad inmediata, que comienza a funcionar como categoría estética» ${ }^{33}$. Otra visión interesante de la cuestión es la que René de Costa traza sobre la poesía de Nicanor Parra, el poeta chileno ${ }^{34}$. Al igual que otros poetas hispanoamericanos de su tiempo, Parra escribe poemas donde el prosaísmo de imágenes y léxico es constante. En opinión de De Costa, esta elección literaria significa hacer una poesía que «sea capaz de ser leída como prosa pero cuya percepción sea poética gracias al equilibrio entre la sintaxis fluida de la narración y la regularidad métrica de las frases $\gg{ }^{35}$. De Costa destaca algunos rasgos coincidentes entre los poetas prosaicos: abandono de la rima y el metro, parlamentos extensos y desorganizados, tendencia a la ruptura del discurso poético (ahora fragmentario) y una retórica que no teme caminar de forma abrupta, incluso a saltos. En los textos se perciben dos niveles discursivos: por un

\footnotetext{
32 Ibid., p. 19.

33 Ibid., p. 21.

34 De Costa, René: «Para una poética de la (anti)poesía», en PARRA Nicanor: Poemas y antipoemas. Madrid: Cátedra, 1988.

35 Ibid., p. 11.
} 
lado, una voz alta, narrativa y evidente; por otro, una voz baja, más reflexiva. El diálogo no se establece sólo con el lector (al que ya no se le habla desde ningún Parnaso), sino entre todas estas voces internas. El sujeto lírico se hace así múltiple, se analiza a sí mismo, cuestiona lo que escribe y se pregunta sobre su identidad. Es éste enfoque el que hace que los poemas prosaicos resulten fascinantes, al oscilar entre el monólogo lírico (la confesionalidad) y la autoironía (dialogismo). Los contrastes llegan a su punto máximo cuando la voz lírica juega directamente a ser antilírica. La retórica desdramatiza el hecho poético, acerca la literatura al lector y anula el sentido de solemnidad del acto de enunciación poética incorporando refranes, frases previsibles y dichos que se insertan en el poema no como elementos prosaicos, sino como argumentos que, gracias a la alteración de las expectativas del lector, producen un efecto que libera a la palabra poética de las fórmulas poéticas más habituales.

Lo objetivo (la realidad) se convierte en el elemento a partir del cual funciona la subjetividad poética, expresada gracias a una sucesión de imágenes encadenadas que pretenden evocar un sentimiento por acumulación de objetos, referentes y efectos narrativos. Es este uso de la enumeración retórica la que permite al poeta transmitir su emoción. Un ejemplo es el «Soneto (no tan) arbitrario ${ }^{36}$ de Benedetti. En este poema el escritor uruguayo demuestra su amplio dominio de las artes métricas clásicas, pero las subvierte mediante una construcción paródica cuyo efecto consistiría justamente en su utilización para cantar una cuestión tan banal como una lista de preferencias literarias y geográficas. Se trata de poesía expresada a través de un lenguaje meramente acumulativo:

CON CIUDADES Y AUTORES FRECUENTADOS

Venecia/Guanajuato/Maupassant/

Leningrado/Sousándrade/Berlín/

Cortázar/Bioy Casares/Medellín/

Lisboa/Sartre/Oslo/Valle Inclán/

Kafka/Managua/Faulkner/Paul Celan/

Italo Svevo/Quito/Bergamín/

${ }^{36}$ Benedetti, Mario: Las soledades de Babel, cit., p. 98. 
Buenos Aires/La Habana/Graham Greene/

Copenhage/Quiroga/Thomas Mann/

Onetti/Siena/Shakespeare/Anatole

France/Saramago/Atenas/Heinrich Böll/

Cádiz/Martí/Gonzalo de Berceo/

París/Vallejo/Alberti/Santa Cruz

de Tenerife/Roma/Marcel Proust/

Pessoa/Baudelaire/Montevideo

Evidentemente, estamos ante un divertimento poético. Benedetti elige una forma culta y abandona el cauce del verso libre en favor de un molde concebido para motivos elevados. Propone un juego retórico a partir de la convención: introduce la vírgula en la mayoría de los versos -salvo donde hay encabalgamientoscon el fin de subrayar su motivación lúdica, ya que el ritmo del poema responde fielmente al modelo clásico (endecasílabo) y tanto su estructura (dos cuartetos y dos tercetos) como su rima no cuestionan en absoluto la tradición. La enumeración lírica produce un efecto de ralentización en la lectura del poema. Aquí no hay ritmo retórico, sino forma métrica. Una enunciación cuyo cauce es el ritmo silábico-acentual de los endecasílabos.

Otro rasgo del prosaísmo lírico es la recurrencia del paralelismo retórico. Se trata de un procedimiento estructural que incide en el figurativo (imágenes). Benedetti lo usa en «No te salves», uno de sus poemas más célebres ${ }^{37}$ :

$\begin{array}{ll}\text { No te quedes inmóvil } & 7 \\ \text { al borde del camino } & 7 \\ \text { no congeles el júbilo } & 7 \\ \text { no quieras con desgana } & 7 \\ \text { no te salves ahora } & 7 \\ \text { ni nunca } & 3 \\ \text { no te salves } & 4 \\ \text { no te llenes de calma } & 7 \\ \text { no reserves del mundo } & 7 \\ \text { sólo un rincón tranquilo } & 7 \\ \text { no dejes caer los párpados } & 7 \\ \text { pesados como juicios } & 7\end{array}$

${ }^{37}$ Benedetti, Mario: Poemas de los otros (Buenos Aires: Alfa, 1974). Madrid: Visor, 1996, p. 313. 


$\begin{array}{ll}\text { no te quedes sin labios } & 7 \\ \text { no te duermas sin sueño } & 7 \\ \text { no te pienses sin sangre } & 7 \\ \text { no te juzgues sin tiempo } & 7 \\ \text { pero si } & 3 \\ \text { pese a todo } & 4 \\ \text { no puedes evitarlo } & 7 \\ \text { y congelas el júbilo } & 7 \\ \text { y quieres con desgana } & 7 \\ \text { y te salvas ahora } & 7 \\ \text { y te llenas de calma } & 7 \\ \text { y reservas del mundo } & 7 \\ \text { sólo un rincón tranquilo } & 7 \\ \text { y dejas caer los párpados } & 7 \\ \text { pesados como juicios } & 7 \\ \text { y te secas sin labios } & 7 \\ \text { y te duermes sin sueño } & 7 \\ \text { y te piensas sin sangre } & 7 \\ \text { y te juzgas sin tiempo } & 7 \\ \text { y te quedas inmóvil } & 7 \\ \text { al borde del camino } & 7 \\ \text { y te salvas } & 4 \\ \text { entonces } & 3 \\ \text { no te quedes conmigo } & 7\end{array}$

La escansión de los versos revela que son heptasílabos (siete sílabas) salvo seis versos (tres trisílabos y otros tres tetrasílabos). Es una aparente irregularidad métrica del poema. En realidad, no es tal: la suma de un trisílabo y un tetrasílabo es equivalente a un heptasílabo. Bedenetti atenúa así el ritmo del poema, pero sin dejar de moverse bajo una medida definida. El ritmo acentual oscila alternativamente, salvo en los versos más cortos. Estos elementos indican que el prosaísmo de Benedetti no tiene vocación rupturista. La rima es libre, con asonancias sueltas. El mecanismo fundamental del poema es estructural. Su ritmo, además de por esta pauta métrica ya mencionada, se ve intensificado gracias al paralelismo léxico, sintáctico y semántico de las dos partes en las que se ordena el texto, que tienen identidad formal pero significado opuesto. En la primera parte del poema usa la anáfora o repetición -los versos empiezan con una negación- mientras que en la segunda se recurre al polisíndeton y a 
la anáfora («y si...»), que repiten, también al comienzo de cada verso, el mismo segmento enunciativo. Benedetti es generoso en las comparaciones («párpados como juicios») terrestres. El texto tiene un ritmo fónico cuyos «esquemas prolonga con periodicidad disminuida y cuya base tradicional amplía con modalidades semánticas o de pensamiento ${ }^{38}$.

Otro ejemplo donde se trabaja con los coloquialismos y la presencia de un yo narrativo explícito es «Otherness» ${ }^{39}$ :

$\begin{array}{ll}\text { Siempre me aconsejaron que escribiera distinto } & 14\end{array}$ que no sintiera emoción sino pathos 11 que mi cristal no fuera transparente 11 sino prolijamente esmerilado 11

y sobre todo que si hablaba del mar $\quad 12$

no nombrara la sal $\quad 7$

siempre me aconsejaron que fuera otro $\quad 12$ y hasta me sugirieron que tenía 11 notorias cualidades para serlo 11

por eso mi futuro estaba en la otredad 14

el único problema ha sido siempre $\quad 11$

mi tozudez congénita $\quad 7$

neciamente no quería ser otro 11

por lo tanto continué siendo el mismo 11

otrosí digo/me enseñaron 9

después que la verdad $\quad 7$

era más bien tediosa $\quad 7$

el amor/cursi y combustible 9

la decencia/bastarda y obsoleta 11

siempre me instaron a que fuera otro $\quad 11$

pero mi terquedad es infinita 11

creo además que si algún día 9

me propusiera ser asiduamente otro $\quad 14$

se notaría tanto la impostura $\quad 11$

que podría morir de falso crup $\quad 11$

o falsa alarma u otras falsías $\quad 10$

es posible asimismo que esos buenos propósitos 14

sean sólo larvadas formas de desamor $\quad 14$

ya que exigir a otro que sea otro 11

en verdad es negarle su otredad más genuina 14

como es la ilusión de sentirse uno mismo 14

$\begin{array}{ll}\text { siempre me aconsejaron que escribiera distinto } & 14\end{array}$

${ }_{38}$ PARAíso, Isabel: El comentario de textos poéticos. Gijón: Júcar, 1988, p. 44.

${ }^{39}$ Benedetti, Mario: Las soledades de Babel, cit., p. 20. 
$\begin{array}{lr}\text { pero he decidido desalentar/humilde } & 14 \\ \text { y cautelosamente a mis mentores } & 11 \\ \text { en consecuencia seguiré escribiendo } & 11 \\ \text { igual a mí o sea } & 7 \\ \text { de un modo obvio irónico terrestre } & 11 \\ \text { rutinario tristón desangelado } & 11 \\ \text { (por otros adjetivos se ruega consultar } & 14 \\ \text { críticas de los últimos treinta años) } & 11 \\ \text { y eso tal vez ocurra porque no sé ser otro } & 14 \\ \text { que ese otro que soy para los otros. } & 11\end{array}$

En este poema no aparece el mismo grado de regularidad que se percibe en No te salves. De los 42 versos, la mayoría responden al patrón del endecasílabo, que condiciona el ritmo general del texto, de naturaleza impar. Este leve distanciamiento con el ritmo silábico obliga al poeta a recurrir a elementos retóricos para mantener la intensidad: repeticiones, una estructura donde se repite el mismo segmento anafórico al comienzo de las estrofas -primera, segunda, quinta y séptima-y otros rasgos prosaicos, como adverbios - considerados poco líricos-, falta de puntuación, utilización de la vírgula, frases retóricas desacostumbradas («otrosí») o los paréntesis. Este último recurso gráfico -en realidad, una marca de cambio de tono- permite a Benedetti tomar la suficiente distancia con la enunciación lírica más convencional, desmitificar al poeta (aquí se corrige a sí mismo y se desdobla) e introducir una ironía que no pone en tela de juicio el sentido último del poema. Su finalidad es acercar el poema al lector y criticar indirectamente el lenguaje pedante de la poesía hermética.

El verso, dada la citada pauta endecasilábica, no es completamente libre. Los recursos retóricos más abundantes son las metáforas $($ cristal=poesía; transparente $=$ clara $)$ y el contraste mediante sinónimos con matices de significado diferentes (emoción frente a pathos). También hay juegos etimológicos (políptoton) que usan la misma raíz léxica (otro/otredad). Incluso se atisban estructuras donde la adjetivación doble se apoya en un único elemento copulativo y repeticiones léxicas («otro», «ser otro») bajo fórmulas en apariencia inclusivas. Esta táctica de adjetivación, con la que Benedetti rompe la expectativa del lector, se formula 
en otros casos sobre la figura del asíndeton. Que el título del poema sea una palabra en inglés no es casual: responde al citado juego de contrastes.

La poesía coloquial está vinculada con la realidad. Sus motivos parten de ella. Su retórica la reproduce. De ahí que Benedetti recurra con frecuencia a la crítica social, a menudo irónica. En «Los pitucos» ${ }^{40}$ tenemos una muestra. Es un poema con estructura narrativa donde el patrón métrico tradicional tampoco termina de desaparecer por completo. El ritmo es impar, con predominio del heptasílabo, pero está quebrado por el empleo de una tipografía engañosa que desarticula el verso. El poema abunda en elementos retóricos de recurrencia (la estrofilla interna, con una rima que hace las veces de eco) y repeticiones. También hay un juego paralelístico similar al de una canción infantil:

$\begin{array}{lc}\text { Hijo mío } & 4 \\ \text { recuérdalo } & 3 \\ \text { son éstos los pitucos } & 7 \\ \text { tienen un aire } & 5 \\ \text { verdad } & 3 \\ \text { que es un desaire } & 5 \\ \text { tienen la marca } & 5 \\ \text { verdad } & 3 \\ \text { de su comarca } & 5 \\ \text { mira } & 2 \\ \text { son los pitucos } & 5 \\ \text { nacen junto a la rambla } & 7 \\ \text { respiran el salitre } & 7 \\ \text { le hacen guiños al sol } & 7 \\ \text { se rascan el ombligo } & 7 \\ \text { duermen siestas feroces } & 7 \\ & \\ \text { besan con labios blandos } & 7 \\ \text { y en la rambla se mueren } & 7 \\ \text { y van al paraíso } & 7 \\ \text { y claro } & 3 \\ \text { el paraíso } & 5\end{array}$

$\overline{40}$ Benedetti, Mario: Poemas del hoyporhoy. (Montevideo: Alfa, 1961). Madrid: Visor, 1991, p. 45. 
es también una rambla

fíjate bien

son ellos

los pitucos

casi una raza aparte

son nietos de estancieros

primos de senadores

sobrinos de sobrinos

de heroicos industriales

son ágiles

imberbes

cornudos

mira cómo te miran

bajo sus lentes negros

pero no te preocupes

en el fondo

son buenos

aman los dividendos

escuchan a Stravinsky

se bañan diariamente

con jabón perfumado

y a la hora del crepúsculo

bajan todos al Centro

hijo mío

prométeme

nunca intentes hacerles

zancadillas

los pitucos son tenues

los pitucos son blandos

una bocina

un grito

a veces una huelga

le arruinan el alma

en ocasiones

raras ocasiones

se hacen los malos

dicen palabrotas

6

pero después se mueren 


\begin{tabular}{lc} 
y allá en su diario íntimo & 7 \\
se azotan con metáforas & 7 \\
hijo mío & 4 \\
recuérdalo & 3 \\
son éstos los pitucos & 7 \\
tienen un pelo & 5 \\
verdad & 3 \\
que es terciopelo & 5 \\
una cadencia & 5 \\
verdad & 3 \\
que es decadencia & 5 \\
& \\
tú & 2 \\
dejálos pasar & 6 \\
son de otra raza & 5 \\
admíralos & 3 \\
toléralos & 3 \\
apláudelos & 3 \\
escúpelos & 3 \\
tírales caramelos & 7 \\
cualquier cosa & 4 \\
después & 3 \\
cuando seas grande & 5 \\
grande & 2 \\
y tengas un hijo & 6 \\
lo tomas de la mano & 7 \\
lo traes aquí a la rambla & 7 \\
y sin darle importancia & 7 \\
le dices & 3 \\
hijo mío & 4 \\
son éstos los pitucos & 7 \\
\hline &
\end{tabular}

El primer rasgo prosaico del poema es el título: una expresión coloquial uruguaya para referirse a los hijos de la burguesía de Montevideo. El texto tiene una extensión considerable (91 versos). Su disposición tipográfica engaña: los versos parecen irregulares, pero la mayoría de ellos son heptasílabos o versos de menos sílabas que, sumados, equivalen a un heptasílabo en unos casos, o a un endecasílabo en otros. A pesar de esta apariencia de versos cortos, el ritmo se impone al oído. Es un recurso habitual en Benedetti, que simula la presencia de un verso libre que sólo lo es de forma relativa. La estructura del poema está marcada 
por los paralelismos, las repeticiones (sintácticas, estróficas y semánticas) y otras figuras de insistencia. Entre las fórmulas retóricas de contraste podemos citar la antítesis, avivada por la rima, o la paronomasia: «aire/desaire»; «cadencia/decadencia». Las anáforas se encuentran situadas para romper la sucesión estrófica: «son éstos los pitucos, verdad». También hay encabalgamientos («ellos/los pitucos»), («hacerles/zancadillas»). El poema tiene una adjetivación sorprendente, al combinar términos cuyo sentido comienza siendo positivo y, de repente, se torna negativo (ágiles, imberbes, cornudos). Los verbos, sobre todo en los versos que son imperativos, incrementan la intensidad del poema, planteado como un falso diálogo (sólo hay un sujeto lírico) entre un padre y un hijo, réplica de la conversación entre el poeta y el lector.

\section{III}

En la obra del poeta uruguayo Mario Benedetti la relación entre la retórica del prosaísmo y la práctica de la métrica en el verso juegan un papel complementario. Por un lado, el poeta marca ciertas distancias con algunos patrones líricos ortodoxos en su afán por acercar la poesía al lector común, cotidiano, sencillo. Por otro lado, esta separación de la convención métrica no llega a cuestionarla por completo, sino únicamente en parte. Debajo de la aparente libertad del verso libre de Benedetti palpita un conocimiento exahustivo del ritmo del verso, hasta el punto de que el escritor uruguayo usa moldes clásicos, como el soneto, para asuntos prosaicos o mantiene el ritmo endecasilábico (o irregular) en la estructura de poemas que aparentemente podrían encuadrarse bajo el concepto de verso libre o sin patrón. Se trata pues de un camuflaje mediante el cual Benedetti intenta flexibilizar y hacer fluir el verso con naturalidad sin romper por completo con algunos de los elementos rítmicos de la poesía más clásica, que se complementan con el empleo de una retórica llena de imágenes y recursos prosaicos. 


\section{Bibliografía utilizada}

\section{Bibliografia primaria}

BENEDETTI, Mario: La víspera indeleble. Montevideo: Prometeo, 1945.

- Sólo mientras tanto. Montevideo: Prometeo, 1950.

- Poemas de la oficina. Montevideo: Número, 1956.

- Poemas del hoyporhoy. Montevideo: Alfa, 1961.

- Noción de patria. Montevideo: Nueva Imagen, 1963.

- Próximo prójimo. Montevideo: Nueva Imagen, 1965.

- Contra los puentes levadizos. Montevideo: Alfa, 1966.

- A ras de sueño. Montevideo: Alfa, 1967.

- Quemar las naves. Madrid: Visor, 1969.

- Letras de emergencia. Buenos Aires: Alfa, 1973.

- Poemas de otros. Buenos Aires: Alfa, 1974.

- La casa y el ladrillo. México DF: Siglo XXI, 1976.

- Cotidianas. México DF: Siglo XXI, 1979.

- Viento del exilio. México DF: Nueva Imagen, 1981.

- Geografias. Madrid: Visor, 1984.

- Preguntas al azar. Montevideo: Arca, 1986.

- Yesterday y mañana. Madrid: Visor, 1987.

- Despistes y franquezas. Madrid: Visor, 1990.

- Las soledades de Babel. Madrid: Visor, 1991.

- El olvido está lleno de memoria. Madrid: Visor, 1995.

- La vida ese paréntesis. Madrid: Visor, 1998.

- Rincón de haikus. Madrid: Visor, 1999.

- El mundo que respiro. Barcelona: Seix Barral, 2001.

- Insomnios y duermevelas. Barcelona: Seix Barral, 2002.

- Existir todavía. Barcelona: Seix Barral, 2003.

- Defensa propia. Barcelona: Seix Barral, 2004.

- Adioses y bienvenidas. Barcelona: Seix Barral, 2005.

- Canciones del que no canta. Barcelona: Seix Barral, 2006.

- Testigo de uno mismo. Barcelona: Seix Barral, 2008.

- Biografía para encontrarme. Madrid: Alfaguara, 2010.

\section{Bibliografía secundaria}

ALEMANY, Carmen: Poética Coloquial Hispanoamericana. Alicante: Universidad de Alicante, 1997.

- con MATAIX, Remedios y ROVIRA, José Carlos (eds.): Mario Benedetti. Inventario Cómplice. Alicante: Universidad de Alicante, 1998. - Mario Benedetti. Madrid: Eneida, 2000.

ALFARO, Hugo: Mario Benedetti (detrás de un vidrio claro). Montevideo: Trilce, 1986. 
MANSOUR, Mónica: Tuya, mía, de otros. La poesía coloquial de Mario Benedetti. México DF: UNAM, 1979.

ZEITZ, Eileen: «Entrevista a Mario Benedetti». Revista Hispania, 1980, 63, pp. 417-418.

AMADO, Alonso: Poesía y estilo de Pablo Neruda. Madrid: Gredos, 1997.

ATRIDGE, Dereck: Poetic Rhythm. An Introduction. Cambridge: Cambridge University Press, 1995.

- y CARPER, Thomas: Meter and Meaning. An Introduction to Rhythm in Poetry. Nueva York: Routledge, 2003.

BÈGUE, Alain: «Degeneración y prosaísmo en la escritura poética de finales del Siglo XVII y principios del XVIII. Análisis de dos nociones heredadas». Revista Criticón, 2008, 103-104, pp. 21-38.

BENEDETTI, Mario: Los poetas comunicantes. México DF: Marcha Editores, 1972.

DE COSTA, René: «Para una poética de la (anti)poesía», en PARRA, Nicanor: Poemas y antipoemas. Madrid: Cátedra, 1988.

DOMÍNGUEZ CAPARRÓS, José: Métrica española. Madrid: Síntesis, 1993.

DUFFELL, MARTIN J.: «The Advent of Free Verse» en A New History of English Metre. Oxford: Legenda, Modern Humanities Research Association and Maney Publishing, 2008.

— «Versifying in English in the Twentieth Century» en A New History of English Metre. Oxford: Legenda, Modern Humanities Research Association and Maney Publishing, 2008.

- «The Principles of Free Verse in English». Rhythmica, Sevilla, 2010, 8, pp. 7-36.

ELIOT, T. S: Sobre poesía y poetas. Buenos Aires: Sur, 1959.

FERNÁNDEZ RETAMAR, Roberto: «Rubén Darío en las modernidades de nuestra América». Ponencia del Congreso Rubén Dario: la tradición y el proceso de modernización. Universidad de Illinois, Mayo, 1988.

- Para una Teoría de la Literatura Hispanoamericana. Santa Fé de Bogotá: Publicaciones del Instituto Caro y Cuervo, 1995.

GAOS, Vicente: Poética de Campoamor. Madrid: Gredos, 1969.

GILI GAYA, Samuel: El ritmo de la poesía contemporánea. Barcelona: Universidad de Barcelona, 1956.

LAUSBERG, Heinrich: Manual de Retórica Literaria. Madrid: Gredos, 1966.

MORTARA GARAVELLI, Bice: Manual de Retórica. Madrid: Cátedra. 1988.

NAVARRO TOMÁS, Tomás: Métrica española. Barcelona: Labor, 1991.

NOGUEROL, Francisca: «Estudio» a la antología Los espejos las sombras. Salamanca: Universidad de Salamanca, 1999.

PARAÍSO, Isabel: El verso libre hispánico. Orígenes y corrientes. Madrid: Gredos, 1985.

— El comentario de textos poéticos. Gijón: Júcar, 1998. 
PAZ, Octavio: El arco y la lira. México DF: Fondo de Cultura Económica, 1972.

- Los hijos del limo. Barcelona: Seix Barral, 1987.

POUND, Ezra: $A B C$ of Reading. Madrid: Fuentetaja, 2000. Traducción de Miguel Martínez Lage.

SILKIN, Jon: The Life of Metrical and Free Verse in Twentieth Century Poetry. Londres: Macmillan Press, 1997.

TORRE, Esteban: Fundamentos de Poética española, en colaboración con Manuel Ángel Vázquez Medel. Sevilla: Alfar, 1986.

- 33 Poemas simbolistas. Madrid: Visor, 1995.

- El ritmo del verso. Estudios sobre el cómputo silábico y la distribución acentual, a la luz de la Métrica Comparada, en el verso español moderno. Murcia: Universidad de Murcia, 1999.

- Metapoiesis. Cuestiones de crítica y teoría. Sevilla: Padilla, 2000. 2012.

TORRES, Daniel: José Emilio Pacheco. Poesía y poética del prosaísmo. Madrid: Pliegos, 1990.

TSUR, Reven: Poetic Rhythm. Structure and Performance. An Empirical Study in Cognitive Poetics. Eastbourne: Sussex Academic Press, 1998.

UTRERA TORREMOCHA, María Victoria: Teoría del Poema en prosa. Sevilla: Universidad de Sevilla, 1999.

- Historia y teoría del verso libre. Sevilla: Padilla, 2001.

- El simbolismo poético. Estética y Teoría. Madrid: Verbum, 2011. 